\title{
Psychometric Properties of the Drug Use Disorders Identification Test (DUDIT) in Heroin Dependent Adults and Adolescents with Drug Use Disorder
}

\author{
Cuneyt Evren', Ethem Ovali ${ }^{2}$, Vahap Karabulut ${ }^{2}$, Sera Cetingok ${ }^{2}$
}

ÖZET:

Madde Kullanım Bozukluğu Tanıma Testi'nin (DUDIT) eroin bağımlısı erişkinlerde ve madde kullanım bozukluğu olan ergenlerde psikometrik özellikleri

Amaç: Bu çalışmanın amacı madde sorunu yaşayan bireyleri tarama amaçlı geliştirilen Madde Kullanım Bozukluğu Tanıma Testi'nin (DUDIT) madde kullanım bozukluğu olan Türk hastalarda pskometrik özelliklerinin değerlendirilmesidir.

Yöntem: Çalışmaya ergenler için madde kötüye kullanımı tedavi programında olan ve madde kullanım bozukluklu 100 ergen, yatılı madde kötüye kullanımı tedavi programındaki 123 erişkin eroin bağımlısı hasta ve aynı klinikten alkol bağımlılı̆ı olan ve madde kötüye kullanımı sorunu bildirmeyen 35 hasta dahil edildi.

Sonuçlar: DUDIT, Madde Kötüye Kullanımı Tarama Testi (DAST-10) ile kıyaslandığında yüksek konverjan geçerlilik ( $r=0.76)$ gösteren ve Cronbach's alfa değeri 0.93 olan psikometrik olarak güvenilir bir madde kötüye kullanımı tarama ölçeği olarak bulunmuştur. Ek olarak tek bileşen toplam varyansın $\% 58.65$ 'ini açıklamıştır. Kesme noktası 10 ve üzeri olarak alındığında DUDIT duyarlılık ve özgüllük puanları sırasıyla 0.96 ve 0.94 olarak bulunmuştur. Ayrıca, DUDIT alkol kullanım bozukluğu olan hastaları madde kullanım bozukluğu olan hastalardan anlamlı düzeyde ayırd ettiği için iyi ayırıcı geçerlilik göstermiştir.

Değerlendirme: Bu bulgular DUDIT'in madde kullanım bozukluğu olan Türk hastalarda tek boyutlu yapıda ölçüm yapan geçerli ve güvenilir madde kötüye kullanımı tarama ölçeği olduğunu desteklemektedir. Ek klinik populasyonlarda ve cezaevi ortamlarındaki gibi yüksek riskli populasyonlarda daha ileri çalışmaların yapılması gerekmektedir.

Anahtar sözcükler: öz bildirim, DUDIT, madde kötüye kullanımı, tarama, güvenirlik, geçerlik

Klinik Psikofarmakoloji Bulteni 2014;24(1):39-48

\section{ABSTRACT:}

Psychometric properties of the Drug Use Disorders Identification Test (DUDIT) in heroin dependent adults and adolescents with drug use disorder

Objective: The aim of the present study was to evaluate the psychometric properties of the Drug Use Disorders Identification Test (DUDIT), developed to screen individuals for drug problems, in Turkish patients with drug use disorder.

Method: Participants included 100 adolescents with drug use disorder in a substance abuse treatment program for adolescents, 123 heroin dependent adults in a residential substance abuse treatment program, and 35 alcohol dependents from the same clinic, who did not report a drug abuse problem.

Results: The DUDIT was found to be a psychometrically sound drug abuse screening measure with high convergent validity $(r=0.76)$ when compared with the Drug Abuse Screening Test (DAST-10), and to have a Cronbach's alpha of 0.93 . In addition, a single component accounted for $58.65 \%$ of total variance, and the DUDIT had sensitivity and specificity scores of 0.96 and 0.94 , respectively, when using the optimal cut-off score of 10. Additionally, the DUDIT showed good discriminant validity as it significantly differentiated patients with drug use disorder from alcohol dependents.

Conclusion: These findings support the DUDIT as a reliable and valid drug abuse screening instrument that measures a unidimensional construct in Turkish patients with drug use disorder. Further research is warranted with both additional clinical populations and with high risk populations such as those in criminal justice settings.

Keywords: self-report, DUDIT, drug abuse, screening, reliability, validity

Bulletin of Clinical Psychopharmacology 2014;24(1):39-48
'Assoc. Prof., ${ }^{2}$ M.D., Bakirkoy Training and Research Hospital for Psychiatry Neurology and Neurosurgery, Research, Treatment and Training Center for Alcohol and Substance Dependence (AMATEM), Istanbul - Turkey

Address reprint requests to: Dr. Cuneyt Evren, Icadiye Caddesi, Mentes Sokak, Selcuk Apt. 1/17, Kuzguncuk 34674 Uskudar, Istanbul - Turkey

Phone: +90-212-409-1515/2111

Fax: $+90-212-409-1595$

E-mail address: cuneytevren@yahoo.com

Date of submission: January 30, 2013

Date of acceptance: March 10, 2013

Declaration of interest:

C.E., E.O., V.K., S.C.: The authors reported no conflict of interest related to this article. 


\section{INTRODUCTION}

One of the several drug abuse screening instruments that have been developed to assess the severity of substance abusers' drug use ${ }^{1}$ is the Drug Use Disorders Identification Test (DUDIT) ${ }^{2}$. The 11-item DUDIT was the result of an extensive literature review and think-aloud testing of three preliminary versions of the measure ${ }^{2}$. Developed as an analogous instrument to the Alcohol Use Disorders Identification Test (AUDIT) ${ }^{3}$, the questions on the DUDIT are parallel to those on the AUDIT with very few exceptions (i.e., two items on the AUDIT were deleted and three new items were added). The DUDIT assesses an individual's illicit drug use and related consequences over the past year and collects data in the following areas: (a) frequency of drug use, (b) drug-related problems, and (c) drug dependence symptoms.

In their initial investigation of the psychometric properties of the DUDIT, Berman et al. ${ }^{2}$ used both general and clinical population samples. For the general population sample, the DUDIT was administered to 1109 randomly selected individuals from the Swedish Population Registry. Using this sample, a Cronbach's alpha of 0.93 was found. Based on their data, the authors recommend that scores of 6 for males and 2 for females be used as cutoff values suggestive of drug-related problems in the general population ${ }^{4}$. The clinical population consisted of 160 individuals, who were either inpatients at an addiction detoxification unit, prison detainees, prison inmates, or probation clients. In this sample, the DUDIT yielded a Cronbach's alpha of 0.80 . Consequently, the authors suggested that scores greater than 25 be used as the cut-off for identifying individuals in clinical populations, who are likely to meet substance dependence criteria $^{2,4}$. Subsequent articles have reported mean (SD) DUDIT scores in substance abusing samples ranging from 16.9 (9.8) for dependent substance abusers who had relapsed ${ }^{5}$ to 31.9 (6.1) for inpatient opiate abusers ${ }^{6}$. The latter study also found that $88 \%$ of this known substance abusing sample scored greater than 25 points on the DUDIT, suggesting that the measure was useful in detecting substance dependence in this population.

Psychometric evaluations of the DUDIT have been mostly studied in Europe (three in Sweden, one in Norway, one in England) with severely dependent drug abusers in highly constrained settings (e.g., detoxification and inpatient units, prisons $)^{2,5-12}$. The measure was also evaluated with less severe substance abusing clinical populations in the United States of America (USA) ${ }^{13}$. All these studies supported the construct of the DUDIT, which was found to be a psychometrically sound drug abuse screening measure with high convergent validity and good discriminant validity. Additional to these, in a sample of 181 Swedish suspected offenders with signs of mental health problems, the DUDIT showed high accuracy for identification of dependency diagnoses and was associated with drug and legal problem severity as a screening tool ${ }^{14}$. Finally, a study conducted in patients with first-episode psychosis in Norway suggested that the DUDIT was a powerful screening instrument (Cronbach's alpha 0.93 for men and 0.96 for women) for detecting drug use disorders in this population ${ }^{15}$. Consistent with these the DUDIT was one of the 13 instruments suggested as being useful in general hospital wards as a screening tool' ${ }^{1}$.

Although a variety of drug use measures currently exist, the DUDIT has several advantages over other instruments. For example, unlike the Addiction Severity Index ${ }^{16}$, the DUDIT's administration time is brief ( $<5 \mathrm{mins}$ ) and it is easy to score. Also, unlike some drug screening measures that inquire about lifetime use (e.g., Cutdown Annoy Guilty Eye-opener Adapted to Include Drugs [CAGE-AID] $)^{17}$, the DUDIT focuses on drug use and drug-related consequences occurring within the past year, thus identifying possible diagnosable drug use problems. Another advantage is that unlike dichotomous scaling (used by the Drug Abuse Screening Test [DAST-10] ${ }^{18}$ and CAGE-AID ${ }^{17}$ ), the questions on the DUDIT are scored using continuous interval scaling which has 
been found to reduce underreporting of drug use and related consequences ${ }^{3}$.

Although the AUDIT has been used widely for alcohol use disorders in Turkey in the last decade $^{3,19}$, currently there is no instrument to measure or detect the presence and severity of drug use disorder. In an effort to filling this gap, the aim of the present study was to evaluate the psychometric properties of the DUDIT ${ }^{2}$, an 11-item self-reported questionnaire developed previously to screen individuals for drug problems, in Turkish patients with drug use disorder.

\section{METHODS}

\section{Participants}

The data were gathered from two treatment centers in Bakirkoy Training and Research Hospital for Psychiatry, Istanbul, Neurology and Neurosurgery.

Adolescents with drug use disorder $(n=100)$ were recruited from inpatients admitted to the Child and Adolescent Substance Treatment and Training Center (CEMATEM), whereas heroin dependents $(n=123)$ and alcohol dependents $(n=35)$ were recruited from the inpatients admitted to the Alcohol and Drug Research Training and Treatment Center (AMATEM). Thus the inclusion criterion was to be an inpatient in these clinics, whereas there were no exclusion criteria for the sample, since these criteria were applied during the admission (e.g., patients with severe psychopathology and/or cognitive deficiency were not admitted). Participants were grouped according to their diagnoses as (a) adolescents with drug use disorder (ADUD; $\mathrm{n}=100$ ), (b) residential heroin dependents (RHD; $\mathrm{n}=123$ ) or (c) alcohol dependents without a drug abuse problem (AD; $n=35)$. The third group was included to evaluate the discriminant validity of the DUDIT. Group membership was based on the substance use disorder module of the Turkish version of the Structured Clinical Interview for the DSM-IV (SCID-I) ${ }^{20,21}$, which was conducted by a psychiatrist who was experienced with the administration of this instrument (C.E.). The AD group did not report any drug use, whereas the RHD and the ADUD groups did not have an alcohol use disorder diagnosis. The patient's written informed consent was obtained after the study protocol was thoroughly explained.

\section{Translation}

The original AQ was independently translated from English into Turkish by two experts in psychiatry. Consensus was reached on a common draft by these experts. This Turkish version was back translated into English by an independent translator.

\section{Measures}

Participants at both adolescent and adult treatment programs completed the DUDIT, the DAST-10 and a short questionnaire gathering demographic and substance abuse history information.

\section{The DAST-10}

The DAST-10 was selected as a comparison measure for the DUDIT because it is frequently used in the drug abuse field and has demonstrated sound psychometric properties ${ }^{22}$. The DAST assesses drug consequences and problem severity in the past year ${ }^{18}$. The original 28-item DAST, modeled after the Michigan Alcoholism Screening Test ${ }^{23}$, has a unidimensional construct when factor analyzed ${ }^{18}$. All versions of the DAST (28-, 20- and 10-item) have been found to have moderate to high levels of validity, sensitivity, and specificity ${ }^{22}$. Since the 10 -item version of the DAST (DAST-10) has comparable sensitivity and specificity to its 28 and 20-item counterparts ${ }^{1}$, the former was used in the present study. For the DAST-10, scores range from 0 to 10 . The Turkish version has a Cronbach's alpha of 0.90 and a single component accounted for $59.35 \%$ of total variance. Additionally, DAST-10 showed good discriminant 
validity as it significantly differentiated patients with drug use disorder from alcohol dependents ${ }^{24}$.

\section{DUDIT}

The DUDIT is an 11-item self-reported questionnaire that was developed to screen individuals for drug problems. As the development and psychometric properties of the DUDIT have been described earlier in the Introduction section, they will not be repeated here. The first nine questions are scored on 5-point scales ranging from 0 to 4 , and the last two are scored on 3-point scales with values of 0,2 , and 4 . Thus, total scores range from 0 to 44, with higher scores suggestive of a more severe drug problem.

\section{Statistical Analyses}

The following strategies were used to investigate the psychometric properties of the DUDIT: (a) convergent validity was evaluated by calculating a Pearson product-moment correlation between the DUDIT and the DAST-10; (b) internal consistency reliability was assessed using Cronbach's alpha and test-retest correlation was used only for the RHD group; (c) factor structure was examined using a principal component analysis (PCA); (d) predictive validity, sensitivity, specificity, and optimal cut-off scores were estimated by constructing a Receiver Operating Characteristic (ROC) curve; and (e) discriminant validity was evaluated using a one-way analysis of variance (ANOVA) of DUDIT scores for the three groups of participants.

\section{RESULTS}

Table 1 presents demographic and substance abuse history variables for the three groups of participants (ADUD, RHD, and AD).

\section{Factor Structure}

To explore the factor structure of the DUDIT, a PCA was performed using all participants $(n=258)$ and for rotation method Varimax with Kaiser normalization was used. Criteria for retaining extracted components on the PCA were: (a) visual inspection of the scree plot to note breaks in size of Eigenvalues between the components, (b) Eigenvalues greater than one, and (c) percentage of variance accounted for by components retained.

To explore construct validity of the scale first exploratory factor analysis than confirmatory factor analysis were conducted. Prior to any further analysis, the adequacy of sample size was verified using the Keiser-Meyer-Olkin (KMO) measurement of sampling adequacy, which was acceptable at 0.93 .

A visual inspection of the scree plot revealed two components accounting for the majority of variance before components started to level off. Two components on the DUDIT reached the criterion of an Eigenvalue greater than one (6.45 and 1.12) and the variance accounted for by these components were $58.65 \%$ and $10.20 \%$ respectively. In the twofactor solution of the principal components analysis, the first eigen value (6.45) was larger than three times of the second eigen value (1.12). Thus, the output for the two-factor solution indicates a unidimensional construct for the measure. The unidimensionality of

\begin{tabular}{|c|c|c|c|c|c|c|}
\hline & \multicolumn{2}{|c|}{$\begin{array}{l}\text { Heroin Dependent Adults } \\
\qquad n=123\end{array}$} & \multicolumn{2}{|c|}{$\begin{array}{l}\text { Adolescents with DUD } \\
\qquad n=100\end{array}$} & \multicolumn{2}{|c|}{$\begin{array}{l}\text { Alcohol Dependents } \\
\qquad \mathrm{n}=35\end{array}$} \\
\hline & Mean & S.D. & Mean & S.D. & Mean & S.D. \\
\hline Age & 28.07 & 7.96 & 16.59 & 0.99 & 49.34 & 11.13 \\
\hline Age of onset of any substance use & 16.04 & 3.12 & 14.02 & 1.74 & 18.46 & 4.46 \\
\hline Age of onset of heroin use & 20.50 & 4.27 & - & - & - & - \\
\hline Female & $\mathrm{n}=11$ & $8.9 \%$ & 0 & 0 & 0 & 0 \\
\hline Education & 8.51 & 2.77 & 6.61 & 2.15 & 9.29 & 3.75 \\
\hline Without employment & $n=87$ & $70.7 \%$ & $n=60$ & $60.0 \%$ & $\mathrm{n}=11$ & 34.4 \\
\hline
\end{tabular}


the scale then was assessed simultaneously with confirmatory factor analysis. As generally accepted, we took criteria as $>0.90$ for GFI, CFI, NFI and IFI, and $<0.08$ for RMSEA when evaluating the fit index ${ }^{25,26}$. Estimation of the model produced a good fit (root mean square error of approximation $[$ RMSEA $]=0.066$, goodness of fit index $[\mathrm{GFI}]=0.941$, adjusted GFI $=0.945$, parsimony $\mathrm{GFI}=0.585$, normed fit index $[\mathrm{NFI}]=0.954$, comparative fit index $[C F I]=0975$, incremental fit index $[\mathrm{IFI}]=0.975$ ).

As seen in Table 2, all item-component loadings were higher than 0.30 and were in the "good" $(0.47)$ to "excellent" (0.83) range. Thus, results from the PCA suggest that the DUDIT assesses a unidimensional construct.

\section{Convergent Validity and Internal Consistency Reliability}

The Pearson product-moment correlation between the DUDIT and DAST-10 scores for all participants $(n=258)$ was high $(r=0.76, p<0.001)$. Internal consistency reliability for the DUDIT, examined by Cronbach's alpha, was also very high (coefficient $\alpha=0.93$ ) (Table 2). Coefficient of test-retest in the heroin dependent group was $\mathrm{r}=0.77, \mathrm{p}<0.001$. Corrected item total correlations for the DUDIT in the total sample are shown in Table 2. Also inter-item and itemtotal correlations for the DUDIT are shown in Table 3.

\begin{tabular}{|c|c|c|c|c|}
\hline Items & 1 & 2 & $\begin{array}{c}\text { Component } \\
1\end{array}$ & $\begin{array}{l}\text { Corrected Item-Total } \\
\text { Correlation }\end{array}$ \\
\hline 1 & & 0.813 & 0.757 & 0.65 \\
\hline 2 & & 0.848 & 0.532 & 0.47 \\
\hline 3 & & 0.594 & 0.708 & 0.71 \\
\hline 4 & 0.644 & & 0.850 & 0.81 \\
\hline 5 & 0.714 & & 0.799 & 0.74 \\
\hline 6 & 0.757 & & 0.842 & 0.79 \\
\hline 7 & 0.717 & & 0.819 & 0.77 \\
\hline 8 & 0.733 & & 0.871 & 0.83 \\
\hline 9 & 0.672 & & 0.747 & 0.68 \\
\hline 10 & 0.808 & & 0.691 & 0.62 \\
\hline 11 & 0.848 & & 0.748 & 0.68 \\
\hline Mean \pm S.D. (Min.-Max.) & & & $26.22 \pm 13.77$ & $(0-44)$ \\
\hline Eigenvalues & 6.45 & 1.12 & 6.451 & \\
\hline$\%$ of Variance & 58.65 & 10.20 & 58.65 & \\
\hline Cronbach's Alpha & 0.93 & 0.77 & 0.93 & \\
\hline DAST-10 & & & $p<0.001$ & \\
\hline
\end{tabular}

Notes: The 11 items of Drug Use Disorders Identification Test (DUDIT) are listed according to the order of magnitude of their loadings obtained on the two factors (Extraction Method: Principal Component Analysis. Rotation Method: Varimax with Kaiser Normalization).

Coefficient of test-retest in heroin dependent group ( $n=123): r=0.77, p<0.001$.

Table 3: Inter-item and item-total correlations for total sample

\begin{tabular}{|c|c|c|c|c|c|c|c|c|c|c|c|}
\hline DUDIT Items & 1 & 2 & 3 & 4 & 5 & 6 & 7 & 8 & 9 & 10 & 11 \\
\hline 2 & 0.58 & & & & & & & & & & \\
\hline 3 & 0.58 & 0.47 & & & & & & & & & \\
\hline 4 & 0.62 & 0.44 & 0.58 & & & & & & & & \\
\hline 5 & 0.48 & 0.35 & 0.54 & 0.62 & & & & & & & \\
\hline 6 & 0.51 & 0.35 & 0.57 & 0.70 & 0.71 & & & & & & \\
\hline 7 & 0.54 & 0.34 & 0.55 & 0.68 & 0.63 & 0.67 & & & & & \\
\hline 8 & 0.57 & 0.38 & 0.57 & 0.83 & 0.68 & 0.74 & 0.70 & & & & \\
\hline 9 & 0.47 & 0.31 & 0.57 & 0.56 & 0.54 & 0.56 & 0.59 & 0.60 & & & \\
\hline 10 & 0.31 & 0.26 & 0.43 & 0.49 & 0.51 & 0.57 & 0.52 & 0.54 & 0.50 & & \\
\hline 11 & 0.38 & 0.21 & 0.52 & 0.54 & 0.58 & 0.59 & 0.59 & 0.60 & 0.56 & 0.69 & \\
\hline DUDIT Total & 0.57 & 0.42 & 0.68 & 0.77 & 0.77 & 0.81 & 0.78 & 0.84 & 0.72 & 0.77 & 0.80 \\
\hline
\end{tabular}


Table 4: Drug use disorder status according to the cut-off point 10

\begin{tabular}{lccccc} 
Cut-off pointa & Sensitivity & Specificity & Kappa & PPP & NPP \\
\hline 8 & 0.97 & 0.91 & 0.86 & 0.99 & 0.84 \\
9 & 0.96 & 0.91 & 0.83 & 0.99 & 0.81 \\
10 & 0.96 & 0.94 & 0.85 & 0.99 & 0.81 \\
11 & 0.95 & 0.94 & 0.81 & 0.99 & 0.75 \\
12 & 0.93 & 0.94 & 0.76 & 0.99 & 0.69 \\
\hline
\end{tabular}

Note. Kappa $=$ Cohen's Kappa; $\mathrm{PPP}=$ positive predictive power; $\mathrm{NPP}=$ negative predictive power. To conserve space, only the two cut-off scores above and below the suggested critical value of 10 are shown. Positive if Greater Than or Equal To

Table 5: Scale scores among total sample according to the drug use disorder status

\begin{tabular}{|c|c|c|c|c|c|c|}
\hline & \multicolumn{2}{|c|}{ Alcohol Use Disorder } & \multicolumn{2}{|c|}{ Drug Use Disorder } & \multirow[b]{2}{*}{$\chi^{2}$} & \multirow[b]{2}{*}{$\mathbf{p}$} \\
\hline & $n=35$ & $\%$ & $n=223$ & $\%$ & & \\
\hline \multicolumn{7}{|c|}{ DUDIT (cut-off=10) } \\
\hline Negative & 33 & 94.30 & 8 & 3.60 & 186.19 & $<0.001$ \\
\hline Positive & 2 & 5.70 & 215 & 96.40 & & \\
\hline mean \pm sd & $2.17 \pm 7.01$ & $30.00 \pm 10.32$ & $t=-20.28$ & $<0.001$ & & \\
\hline
\end{tabular}

\section{Predictive Validity, Sensitivity, Specificity, and Optimal Cut-Off Scores}

The DUDIT's predictive validity, sensitivity, and specificity were examined using a ROC curve that included all participants $(\mathrm{n}=258)$. Participants were dichotomously classified according to the SCID-I as a group with alcohol use disorder or a group with drug use disorder. Results revealed that the area under curve (AUC) (0.975- Std. Error=0.018) was in the "excellent" range and that a score of 10 was the most critical value for identifying a participant as having a drug problem. As seen in Table 4, this cut-off score corresponds to sensitivity and specificity values of 0.96 and 0.94 , respectively.

Table 5 shows the comparison of alcohol use disorders with drug use disorders according to the cut-off point 10 on the DUDIT and mean scores of the DUDIT.

\section{Concurrent Validity}

To evaluate concurrent validity, a one-way ANOVA was conducted using the total mean score on the DUDIT as the dependent variable and the participants' group membership (ADUD, RHD, AD) as the independent variable. The assumptions of homogeneity of variance and normal distribution of scores were tenable. The result of ANOVA for the DUDIT was statistically significant, F $(2,255)=223.42, p<0.001$. Post-hoc analysis using Tukey's procedure revealed that the mean (SD) DUDIT score for the RHD group, 35.26 (6.77) was higher than the scores in both the ADUD group, 23.52 (10.27), $\mathrm{p}<0.001$ and the AD group, 2.17 (7.01). Finally, the DUDIT mean score was significantly higher in the ADUD group as compared to the AD group $(\mathrm{p}<0.001)$.

\section{DISCUSSION}

The DUDIT was developed to identify individuals in the general public, who may have a drug problem as well as individuals in clinical settings, who are likely to meet criteria for a substance dependence diagnosis ${ }^{2}$. Previous studies were mostly conducted in Europe and only one study was conducted in the USA. The present study extended the evaluation of the psychometric properties of the DUDIT to treatment seeking patients with drug use disorder in Turkey.

Overall, the DUDIT was found to have satisfactory psychometric characteristics as a drug abuse screening test. Consistent with a previous study ${ }^{13}$ conducted in the USA $(r=0.85)$, 
the instrument's high correlation with DAST-10 indicated a good convergent validity $(r=0.76)$. The DUDIT also showed good discriminant validity as evidenced by its ability to significantly differentiate drug use disorders from alcohol dependents. Also, similar to the study conducted in the USA $(0.94)^{13}$ and higher than the original study $(0.80)^{2}$, the Turkish version of the scale had high internal consistency reliability (Cronbach's alpha $=0.93$ ). Finally, PCA for the DUDIT produced a unidimensional construct, with a single component accounting for $58.65 \%$ of the total variance. This rate was $64.91 \%$ in the USA study ${ }^{13}$. In the present study, using Confirmatory Factor Analyses provided further support for the unidimensional structure of the DUDIT. The ROC curve showed that the DUDIT had good predictive validity as suggested by high sensitivity, specificity, and the AUC. Results revealed that a cut-off score of 10 was the most critical value for identifying participants as having an drug use disorder according to the SCID-I. While this cutoff point was similar in the USA study (cut-off score of 8$)^{13}$, it was lower when compared to that of the Swedish study (cut-off score of 25) ${ }^{2}$. This difference can be explained by the sample difference that the present study included an adolescent sample with less severe drug abuse histories than the Swedish study ${ }^{2}$ and similarto that of the USA study ${ }^{13}$. Indeed, the sample of the present study was more similar to the USA study (which included patients with drug use disorder and alcohol use disorder), rather than the Swedish study (which included a sample of heavy drug users from prison, probation, and inpatient detoxification settings, and a general Swedish population sample). Also in a study conducted in a sample of 181 Swedish suspected offenders Durbeej et al. ${ }^{14}$ suggested that cutoff scores should be applied with caution due to the discrepancy between studies.

In previous studies conducted among substance abusing samples mean (SD) DUDIT scores were 16.9 (9.8) for substance abusers who had relapsed ${ }^{5}, 31.9$ (6.1) for inpatient opiate abusers, 23.5 (11.0) for outpatient drug abusers and
26.0 (12.4) for residential drug abusers ${ }^{13}$. These mean scores were consistent with the present study that mean (SD) DUDIT scores were 23.5 (10.3) for adolescents with drug use disorder and 35.3 (6.8) for adults with heroin dependence.

In addition to having good psychometric characteristics, the DUDIT has an advantage over other drug abuse screening instruments, because it is brief, not substance specific, and inquires about use and consequences within the past 12 months, consistent with the DSM-IV-TR interval criterion for diagnosis. As compared to the DAST-10, the DUDIT has the advantage of gathering information about quantity and frequency of drug use. The present study has one main limitation, which concerns the homogeneity of the sample. Specifically, about half of all drug abusers in the present study were adults dependent to heroin and the other half were adolescents with different drug use disorders. There were no female participants in the ADUD and AD groups and data could have been collected from healthy controls as well. The sample size was adequate for the analyses, but larger studies may provide better results. Thus, future research will need to evaluate the DUDIT's characteristics using a larger and more heterogeneous sample of both female and male drug abusers. Finally test-retest reliability was only conducted for the RHD group, whereas it should have been conducted also for the ADUD group.

In conclusion, the present study extended the evaluation of the psychometric properties of the DUDIT to both adult and adolescent populations with drug use disorder and supported the unidimensional construct of the DUDIT in Turkish patients with drug use disorder. This and previous studies support the use of the DUDIT in various clinical settings and encourage continued research into its use.

\section{Acknowledgment}

We would like to thank Psychiatrist Elif Mutlu for handing out self-rating scales to 123 inpatients with substance abuse and transferring this data to the statistic program. 


\section{References:}

1. Mdege ND, Lang J. Screening instruments for detecting illicit drug use/abuse that could be useful in general hospital wards: a systematic review. Addict Behav 2011;36(12):11119. [CrossRef]

2. Berman A, Bergman H, Palmstierna T, Schlyter F. Evaluation of the Drug Use Disorders Identification Test (DUDIT) in criminal justice and detoxification settings and in a Swedish population sample. Eur Addict Res 2005;11(1):2231. [CrossRef]

3. Saunders J, Aasland O, Babor T, de la Fuente J, Grant M. Development of the Alcohol Use Disorders Identification Test (AUDIT):WHO collaborative project on early detection of persons with harmful alcohol consumption-II. Addiction 1993;88(6):791-804. [CrossRef]

4. Berman A, Bergman H, Palmstierna T, Schlyter F. Drug Use Disorders Identification Test manual. Stockholm, Sweden: Karolinska Institutet, 2005.

5. Landheim AS, Bakken K, Vaglum P. Impact of comorbid psychiatric disorders on the outcome of substance abusers: A six year prospective follow-up in two Norwegian counties. BMC Psychiatry 2006;6(10):44. [CrossRef]

6. Berman A, Källmén H, Barredal E, Lindqvist P. Hopeless patients? A study of illicit opiate users who drop out from in-patient detoxification. J Subst Use 2008;13(2):121-30. [CrossRef]

7. Bakken K, Landheim A, Vaglum P. Axis I and II disorders as long-term predictors of mental distress: A six-year prospective follow-up of substance dependent patients. BMC Psychiatry 2007;7:29. [CrossRef]

8. Bakken K, Vaglum P. Predictors of suicide attempters in substancedependent patients: A six-year prospective followup. Clin Pract Epidemiol Ment Health 2007;3:20. [CrossRef]

9. Cruce G, Nordstrom LG, Ojehagen A. Risky use and misuse of alcohol, drugs, and cigarettes detected by screening questionnaires in a clinical psychosis unit. Nord J Psychiatry 2007;61(2):92-9. [CrossRef]

10. Cruce G, Ojehagen A. Risky use of alcohol, drugs, and cigarettes in a psychosis unit: A $11 / 2$ year follow-up of stability and changes after initial screening. BMC Psychiatry 2007;7:31. [CrossRef]

11. Hodgins S, Alderton J, Cree A, Aboud A, Mak T. Aggressive behaviour, victimization, and crime among severely mentally ill patients requiring hospitalisation. Br J Psychiatry 2007;191:343-50. [CrossRef]

12. Hodgins S, Cree A, Alderton J, Mak T. From conduct disorder to severe mental illness: Associations with aggressive behaviour, crime, and victimization. Psychol Med 2008;38(7): 975-87. [CrossRef]

13. Voluse AC, Gioia CJ, Sobell LC, Dum M, Sobell MB, Simco ER. Psychometric properties of the Drug Use Disorders Identification Test (DUDIT) with substance abusers in outpatient and residential treatment. Addict Behav 2012;37(1):36-41. [CrossRef]
14. Durbeej N, Berman AH, Gumpert $\mathrm{CH}$, Palmstierna T, Kristiansson M, Alm C. Validation of the Alcohol Use Disorders Identification Test and the Drug Use Disorders Identification Test in a Swedish sample of suspected offenders with signs of mental health problems: results from the Mental Disorder, Substance Abuse and Crime study. J Subst Abuse Treat 2010;39(4):364-77. [CrossRef]

15. Nesvåg R, Lange EH, Faerden A, Barrett EA, Emilsson B, Ringen PA, et al. The use of screening instruments for detecting alcohol and other drug use disorders in firstepisode psychosis. Psychiatry Res 2010;177(1-2):228-34. [CrossRef]

16. McLellan AT, Luborsky L, Woody GE, O'Brien CP. An improved diagnostic evaluation instrument for substance abuse patients: The Addiction Severity Index. J Nerv Ment Dis 1980;168(1):26-33. [CrossRef]

17. Brown R, Rounds L. Conjoint screening questionnaires for alcohol and other drug abuse: Criterion validity in a primary care practice. Wisconsin Medical Journal, 1995;94(3):135-40.

18. Skinner H. The Drug Abuse Screening Test. Addict Behav 1982;7(4):363-71. [CrossRef]

19. Saatçioğlu Ö, Evren C, Çakmak D. Alcohol use disorders identification test the validity and reliability.. Türkiye'de Psikiyatri 2002; 4(2-3):107-13. (Turkish)

20. First MB, Spitzer RL, Gibbon M, Williams JBW. Stuructured Clinical Interview for DSM-IV Axis I Disorders (SCID-I), Clinical Version. Washington D.C. and London. American Psychiatric Press, Inc, 1997.

21. Corapcioglu A, Aydemir O, Yildiz M, Esen A, Koroglu E. DSMIV Axis I Disorders (SCID-I) Structured Clinical Interview for Clinical Version. Hekimler Yayın Birliği, Ankara, 1999. (Turkish)

22. Yudko E, Lozhkina O, Fouts A. A comprehensive review of the psychometric properties of the Drug Abuse Screening Test. J Subst Abuse Treat 2007;32(2):189-98. [CrossRef]

23. Gibbs LE. Validity and reliability of the Michigan Alcoholism Screening Test: A review. Drug Alcohol Depend 1985;12(3):279-85. [CrossRef]

24. Evren C, Ovalı E, Cetingok S, Karabulut V, Mutlu E. Psychometric properties of the Drug Abuse Screening Test (DAST-10) with heroin dependent adults and adolescents with drug use disorder. Dusunen Adam Journal of Psychiatry and Related Science 2013;26(4):351-9. [CrossRef]

25. Byrne BM. Structural equation modeling with AMOS: Basic concepts, applications and programming. $2^{\text {nd }}$ Ed. New York: Taylor \& Francis, 2010.

26. Hair JF, Anderson RE, Tatham RL, Black WC. Multivariate Data Analysis. $7^{\text {th }}$ ed. New Jersey: Prentice-Hall, 2010. 


\section{Dosya no}

\section{DUDIT Drug Use Disorders Identification Test}

Burada maddeler hakkında birkaç soru vardır. Lütfen mümkün olduğunca doğru ve dürüst bir şekilde sizin için hangi cevabın doğru olduğunu belirterek cevaplayın.

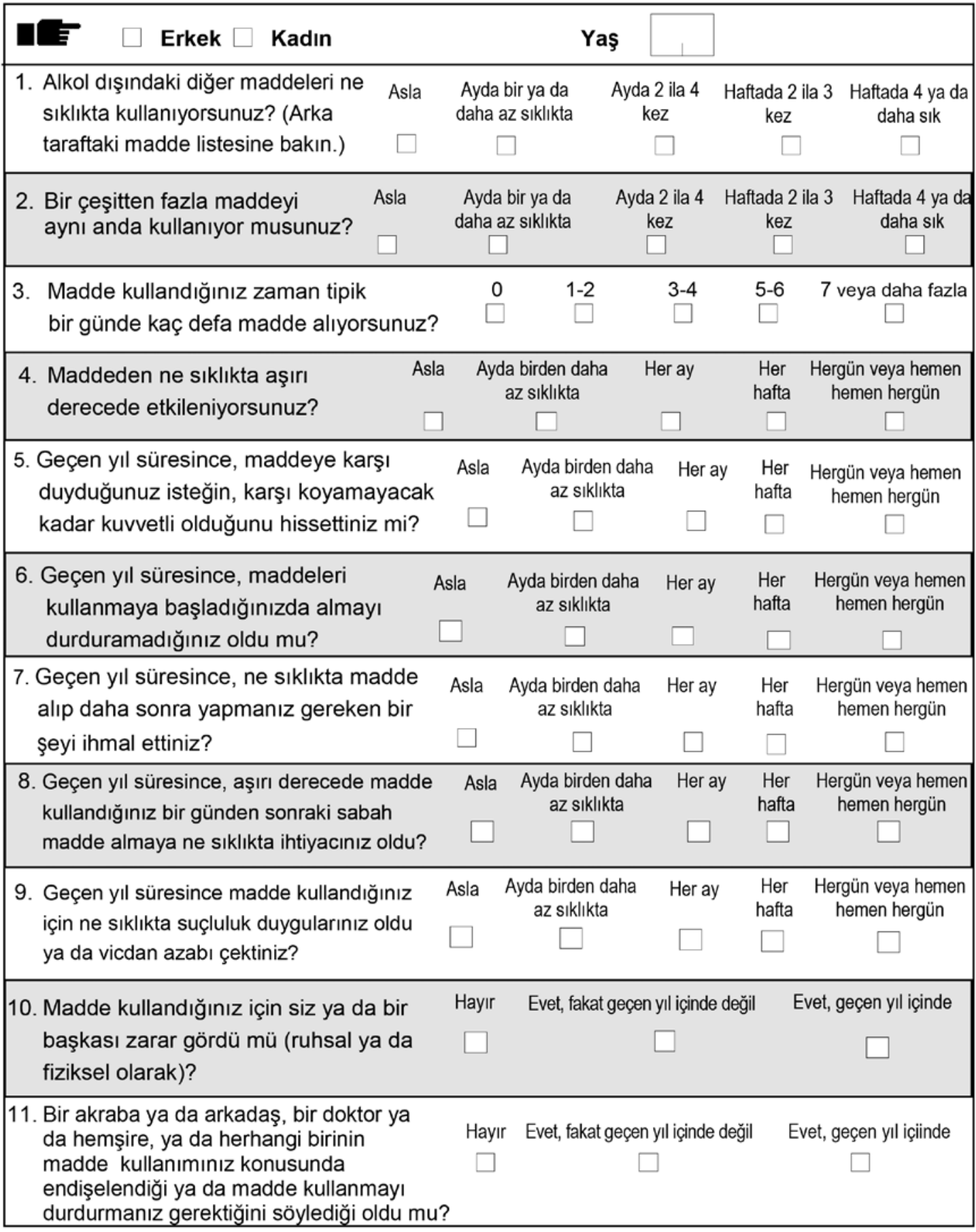




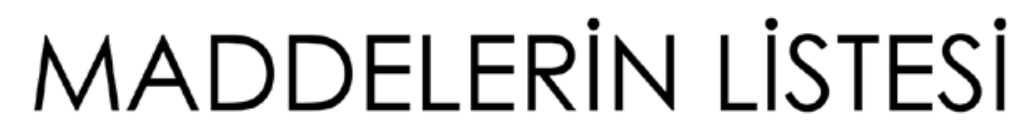

(Dikkat! Alkol değil!)

\begin{tabular}{|c|c|c|c|c|c|c|}
\hline Esrar & Amfetaminler & Kokain & Opiatlar & Halusinojenler & Uçucular/nnhalantlar & Diğerleri \\
\hline $\begin{array}{l}\text { Marijuana } \\
\text { Kannabis } \\
\text { Joint } \\
\text { Kubar } \\
\text { Ot } \\
\text { Haşiş } \\
\text { Bonzai }\end{array}$ & $\begin{array}{l}\text { Khat } \\
\text { Concerta }{ }^{\circledR} \\
\text { Ritalin } ₫ \\
\text { (Metilfenidat) } \\
\text { Dekstroamfetamin } \\
\text { Metamfetamin } \\
\text { Captagon® } \\
\text { (Fenetilin) } \\
\text { Dexedrine® } \\
\text { Modiodal@ } \\
\text { (Modafinil) }\end{array}$ & $\begin{array}{l}\text { Taş (Crack) } \\
\text { Freebase }\end{array}$ & $\begin{array}{l}\text { Koreks } \\
\text { Eroin } \\
\text { Opium } \\
\text { Haşhaş } \\
\text { Afyon sakızı } \\
\text { Morfin } \\
\text { Kodein }\end{array}$ & $\begin{array}{l}\text { Ecstasy (MDMA) } \\
\text { LSD (Liserjik asit) } \\
\text { Meskalin (Kaktüs) } \\
\text { PCP (Melek tozu) } \\
\text { (Fensiklidin) } \\
\text { Psilosibin (Sihirli } \\
\text { Mantar) } \\
\text { Ketamin } \\
\text { Ketalar® } \\
\text { DMT } \\
\text { (Dimetiltriptamin) }\end{array}$ & $\begin{array}{l}\text { Tiner } \\
\text { Soğutucu sprey } \\
\text { (Trikloretilen) } \\
\text { Benzin/petrol } \\
\text { Gaz } \\
\text { Bally } \\
\text { LPG (Çakmak gazı) }\end{array}$ & $\begin{array}{l}\text { GHB (Gama } \\
\text { Hidroksi Bütürat) } \\
\text { Anabolik steroidler } \\
\text { Gülme gazı } \\
\text { (Halotan) } \\
\text { Amil nitrat } \\
\text { (Poppers) } \\
\text { Antikolinerijkler } \\
\text { Akineton (Biperiden) } \\
\text { Maraş Otu } \\
\text { Boru Otu (Güzel } \\
\text { Avrat Otu) }\end{array}$ \\
\hline
\end{tabular}

\section{HAPLAR - ILAÇLAR}

\section{Haplar madde olarak sayılır}

- fazla aldığınızda ya da doktorun sizin için reçete ettiğinden daha sık aldığınızda

- hapları eğlenmek, iyi hissetmek, "kafayı bulmak" istediğiniz ya da sizde nasıl bir etki yapacaklarını merak ettiğiniz için aldığınızda

- akraba ya da arkadaştan aldığınız haplar

- "kara borsa"dan ya da çalınmış haplar satın aldığınızda

\section{UYKU HAPLARI/SEDATIFLER}

Alprazolam

Xanax®

Diazepam

Diazem®

Nervium $®$

Zopiklon

Imovane®

Meprobamate

Danitrin ${ }^{\circledR}$

Zopiklon

Klonazepam

Rivotril ${ }^{\circledR}$

Lorazepam

Ativan®
Klordiazepoksid

Klorazepat Dipotasyum

Fenobarbital

Luminal®

Difenhidramin

Hidroksizin

Atarax®

Flunitrazepam

Rohypno|® (Roş)

\section{AĞRI KESICILER}

Buprenorfin

Suboxone ${ }^{\circledR}$

Temgesic®

Fentanil

Durogesic $₫$

Actiq®

Kodein

Dekstrometorfan

Tramadol

Contramal ${ }^{\circledR}$

Parasetamol

Hidromorfon
Jurnista®

Petidin

Aldolan®

Profenid

Benzidamin

Tantum® 